\title{
MOŽNOSTI VYUŽITIA METÓDY LESSONS LEARNED V RIADENÍ OUTSOURCINGU
}

\author{
Soňa Jirásková
}

Kl’účové slová:

outsourcing, Lessons Learned, manažment, výskum, ozbrojené sily

\section{Key words:}

outsourcing, Lesson Learned, management, research, armed forces

\begin{abstract}
Abstrakt
Článok sa zaoberá možnost’ami využitia metódy Lessons Learned v riadení outsourcingových procesov. Prezentuje čiastkové zistenia z empirického prieskumu outsourcingu, ktorý je realizovaný v Ozbrojených silách Slovenskej republiky. Zámerom príspevku je predstavit' odporúčania, ktoré by viedli k zvýšeniu účinnosti riadenia outsourcingu.
\end{abstract}

\begin{abstract}
The paper deals with possibilities of utilization Lessons Learned method in management of outsourcing process. It presents selected finding of empirical research of outsourcing which is realized in The Slovak Armed Forces. The purpose e of this article is to bring some advices how to upgrading practices of managing outsourcing.
\end{abstract}

\section{Úvod}

Obdobie, v ktorom sa nachádza súčasná spoločnost' je možné označit’ ako „vek učenia sa“. Čoraz častejšie sa možno stretnút' s pojmom „učiaca sa organizácia“, hovorí sa o využívaní dát, informácií, skúseností, znalostí, vedomostí a zručností. Na úspešnost' organizácie má stále väčší vplyv jej schopnost' neustále zvyšovat' svoju výkonnost' prostredníctvom učenia sa. Dve organizácie môžu byt' vybavené majetkom na rovnakej kvalitatívnej úrovni, môžu disponovat' približne rovnakým objemom kapitálu, jedna z nich však môže prosperovat' lepšie. To, čo odlišuje skutočne úspešnú organizáciu od neúspešnej, sú kvalitní pracovníci a úroveň ich znalostí (teoretických vedomostí a praktických zručností). Nevyhnutné je využívat' všetky skúsenosti a neustále sa učit', pričom proces učenia sa by mal mat' permanentný charakter.

Základnou podmienkou učenia sa organizácie je, aby dochádzalo k pravidelnej výmene informácií a k diskusiám. Ak sa chce organizácia zmenit' na znalostnú, musí si vybudovat' systém znalostí - databázu informácií, ktorá by bola prístupná všetkým pracovníkom. V progresívnych organizáciách sa tak zavádza formalizovaný systém manažmentu znalostí. Jednotlivci v ňom majú prístup ku skúsenostiam ostatných a zároveň majú možnost' do systému prispievat' svojimi skúsenost'ami. Učenie v konečnom dôsledku prináša inovácie a inovačné prístupy sú neustálym podnetom $\mathrm{k}$ d'alšiemu učeniu.

Súčast'ou učenia sa je i využívanie skúseností z minulých aktivít. Najväčšou chybou je opakovanie rovnakých „starých“ chýb. Organizácia by sa mala poučit' z minulých činností a skúsenosti využit' ako zdroj hl'adania správnych riešení. Je užitočné pokračovat' v dobrých postupoch, zlé vyradit' a takto predchádzat' neskorším možným problémom. Uvedený postup 
je možné označit’ anglickým pojmom „Lessons Learned“, ktorý by sa do slovenčiny dal preložit’ ako ,ponaučenie zo skúseností““.

\section{Teoretické vymedzenie pojmu „Lessons Learned““}

Pojem Lessons Learned sa v odborných a vedeckých zdrojoch objavuje v súvislosti s projektovým a vedomostným manažmentom. Zůna (2008) proces Lessons Learned vymedzuje ako špecifický informačný proces, ktorého poslaním je zber, vyhodnocovanie oprávnenosti, spracovanie, ukladanie, šírenie a spätné využívanie poznatkov alebo skúseností. Výstupom z procesu sú špecifické informácie, ktoré slúžia ako podklad pre rozhodnutie manažéra. Ciel'om by mala byt' identifikácia a náprava nedostatkov vo vlastných procesoch organizácie a zdiel'anie a šírenie osvedčených praktík. Takýto postup by mal v konečnom dôsledku viest' k d'alšiemu skvalitňovaniu vnútorných procesov v organizácii.

Metóda Lessons Learned sa úspešne využíva v ozbrojených silách viacerých štátov. V Severoatlantickej aliancii je vytvorená samostatná agentúra „Joint Analysis and Lessons Learned Centre - JALLC“ so sídlom v Portugalsku. Taktiež bohatú históriu a dobre rozpracovaný projekt využívania Lessons Learned má americké centrum „Center for Army Lessons Learned“ v Kansase. Tieto centrá zhromažd’ujú, analyzujú, vydávajú, integrujú a archivujú poznatky, skúsenosti, taktické a technické postupy ozbrojených síl za účelom ich využitia v prospech celého spektra vojenských operácií (Kudlička, 2010).

Ozbrojené sily Slovenskej republiky sa taktiež pokúšajú o zavedenie podobného systému už niekol'ko rokov. V roku 2008 bola vydaná „Smernica náčelníka Generálneho štábu Ozbrojených síl Slovenskej republiky o získavaní poznatkov a využívaní skúseností“, ktorá znamenala oficiálny začiatok implementácie tejto metódy. Ciel'om procesu Lessons Learned je zhromažd'ovanie poznatkov, ich identifikácia a zovšeobecȟovanie skúsenosti s pozitívnym alebo negatívnym dopadom na činnost' jednotlivých zložiek ozbrojených síl za účelom prijatia opatrení na odstránenie chýb a zlepšenie podmienok v budúcnosti.

Filozofia projektu Lessons Learned spočíva $\mathrm{v}$ predpoklade, že do databázy informačného systému projektu budú jednotliví užívatelia vkladat' konkrétne informácie, ktorých využitie je potrebné a užitočné i pre d'alších zainteresovaných užívatel'ov. Predpokladá sa, že systém bude možné využit' ako zdroj na poučenie z reálnych situácií. Užívatelia budú môct' ostatným záujemcom prostredníctvom vyplnenia štandardizovaného formulára oznámit' existenciu novej situácie, oznámit' zmenu pôvodnej situácie, odporučit' zmenu konania, prípadne oznámit' svoj osobný postreh k danej predmetnej veci. Dôležité je, aby sa profesionálni vojaci naučili rozpoznat', ktoré skutočnosti je potrebné považovat' za skúsenost' vhodnú na zverejnenie a mali záujem diskutovat' problémy v skupine osôb bezprostredne zainteresovanej na vykonávaní nejakej činnosti, či plnení úlohy. Základom je zodpovedanie na tri základné otázky:

1. Čo bolo dobré?

2. Čo bolo zlé?

3. Čo mohlo byt' lepšie?

Štandardizovaný formulár hlásenia o pozorovaní (identifikovanej skúsenosti, ponaučení zo skúsenosti) obsahuje názov (pomenovanie) udalosti, zistenie (pozorovanie, postreh), opis udalosti (zistenia, pozorovania), závery, odporúčania a termín očakávanej doby splnenia nápravných opatrení.

Databáza spracovaných informácií by mala byt’ prístupná pre všetkých zainteresovaných, mala by sa sústavne dopíňat' o nové poznatky, priebežne aktualizovat', revidovat' a poznatky, 
ktoré stratili svoje opodstatnenie by mali byt' z databázy odstraňované. Systém by nemal byt' chápaný len ako prostriedok na oznámenie negatívneho javu, takisto by sa nemal využívat' na vyjadrenie osobnej nespokojnosti (st'ažnosti) užívatel'a, nemal by sa využívat' ako istý druh kontroly. Zámerom je, aby sa doňho zadávali informácie ako o negatívnych javoch, tak aj o javoch a postupoch pozitívnych, ale predovšetkým informácie, ktoré by viedli k zlepšeniu existujúcej situácie (Majchút, 2010). Informácie v databáze by sa mali dotýkat' aktivít v nasledovných oblastiach:

1. operácie (misie),

2. výcvikové aktivity,

3. cvičenia,

4. výskum (odborné a vedecké skúmanie alebo pozorovanie),

5. d'alšie činnosti a procesy v rezorte Ministerstva obrany Slovenskej republiky.

Za poznatok je možné považovat' každú odchýlku od očakávaného výsledku, z ktorej je možné sa poučit'. Pri každej aktivite existuje očakávaný výsledok alebo výstup. Ak sa očakávania nenaplnia alebo sú prekročené, je to príležitost' poučit' sa. Poznatok môže byt' pozitívny alebo negatívny a podl'a toho sa rozlišuje:

- Lessons Identified (LI) - identifikovaný poznatok - je poznatok z pozorovania, ktorý prešiel analýzou a výsledkom analýzy je príprava krokov a opatrení na nápravu.

- Lessons Learned (LL) - ponaučenie zo skúseností - je výsledok implementácie nápravných opatrení, ktoré priniesli zvýšený a kvalitnejší výkon alebo posilnili či rozšírili spôsobilosti.

Proces Lessons Learned pozostáva z nasledovných krokov (Jirásková, 2011):

1. Pozorovanie a získavanie poznatkov z pozorovania.

2. Analýza.

3. Schválenie záverov analýzy.

4. Vznik identifikovaného poznatku (Lessons Identified).

5. Realizácia opatrení a monitorovanie.

6. Overenie účinnosti vykonaných opatrení.

7. Ponaučenie zo skúsenosti (Lessons Learned).

8. Zdiel'anie informácií o ponaučeniach zo skúseností.

Je vel'mi dôležité, aby poznatky boli aplikovatel'né aj v budúcnosti. Pri posudzovaní poznatku a hodnotení faktov je nutné skúmat' nielen to, aká je pravdepodobnost' toho, či sa jav bude opakovat', ale aj jeho vplyvy na operáciu, organizáciu, personál (tím, skupinu, jednotku a pod.) alebo materiál. Je nutné striktne rozlišovat', či daný poznatok o jave bol ojedinelý v určitom čase, organizácii alebo situácii s vel'mi malou pravdepodobnost’ou jeho opakovania $\mathrm{v}$ budúcnosti. Takýto poznatok je nevhodný pre zavedenie do databázy. Užívatelia by sa mali naučit' rozpoznat' čo považovat' za skúsenost' vhodnú na zaradenie do procesu Lessons Learned. Názorne je možné poznatky rozčlenit’ do nasledovných skupín:

Tabul'ka 1 Členenie poznatkov

\begin{tabular}{|l|c|c|}
\hline & $\begin{array}{c}\text { Vysoká pravdepodobnost' } \\
\text { opakovania }\end{array}$ & $\begin{array}{c}\text { Nízka pravdepodobnost' } \\
\text { opakovania }\end{array}$ \\
\hline $\begin{array}{l}\text { Vysoký vplyv } \\
\text { na budúcu činnost' }\end{array}$ & Vhodné & Vhodné \\
\hline $\begin{array}{l}\text { Nízky vplyv } \\
\text { na budúcu činnost' }\end{array}$ & Vhodné & Nevhodné \\
\hline
\end{tabular}

Zdroj: vlastné spracovanie 
V súčasnom období sa do databázy poznatkov a skúseností ukladajú informácie dotýkajúce sa predovšetkým aktivít z pôsobenia Ozbrojených síl Slovenskej republiky v operáciách a misiách medzinárodného krízového manažmentu. Podl'a charakteru a vzt'ahu zovšeobecneného poznatku je možné využit' ho v rámci celých ozbrojených síl, alebo len v podmienkach úzko špecializovaných vojenských jednotiek. Je dôležité, aby získané skúsenosti boli čo najrýchlejšie zapracované aj do vnútorných predpisov a vojenských doktrín. Možno usúdit', že spracované poznatky predstavujú organizačný kapitál, pod ktorým možno chápat' súhrn vedomostí, ktoré vlastní organizácia a ktoré sú uložené a prístupné v rozličných databázach, manuáloch apod. Hodnota procesu Lessons Learned nadobúda svoj význam len vtedy, ked’ informácie vytvorené týmto procesom sú kedykol’vek prístupné osobám, ktoré ich potrebujú. Do uvedenej databázy je v budúcnosti vhodné zaradit' i informácie a poznatky, ktoré sa dotýkajú i iných vnútorných procesov existujúcich $\mathrm{v}$ ozbrojených silách, napríklad dotýkajúcich sa outsourcingu.

\section{Charakteristika outsourcingu a ciel' jeho prieskumu realizovaného v rezorte obrany Slovenskej republiky}

V Ozbrojených silách Slovenskej republiky sa od roku 2004 využíva nový spôsob zabezpečenia pomocných obslužných činností v oblasti vojenskej logistiky, a to dodávatel'sky formou outsourcingu. Ide o nasledovné aktivity: služba stravovania, upratovania, prania, čistenia a opráv odevov a bielizne, služba fyzickej ochrany objektov, služba prevádzky tepelne - technických zariadení, služba obsluhy čističiek odpadových vôd, vodných zdrojov a hydrofórových staníc, odvoz nebezpečných odpadov, zabezpečovanie zimnej a letnej údržby ciest a vonkajších priestorov vo vojenských objektoch a zariadeniach, opravy a revízie nevojenskej techniky (meracích prístrojov, polygrafických strojov, kopírovacej techniky, renovácia tonerov), servisné prehliadky, opravy, údržba, umývanie a pneuservisné služby osobných automobilov, údržba zariadení výrobných hál, zabezpečovanie chemických WC pri vojenských cvičeniach a zabezpečovanie rekondičných pobytov pre osobitné kategórie zamestnancov.

Outsourcing je moderná metóda manažmentu, ktorú možno definovat' nasledovne (Lednický, 2004): "Outsourcing predstavuje systém úmyselného a ciel'avedomého vyčleňovania a odovzdávania (delegovania) činnosti externému partnerovi, čo má za následok nákup tovaru či služieb od cudzích podnikov namiesto vykonávania týchto činností vo vlastnej réžii. Jedná sa o vyčleňovanie skôr vykonávaných činností, ktoré majú charakter doplnkový a v prevažnej väčšine netvoria pridanú hodnotu, ale pritom sú nevyhnutné. Outsourcing je taký stav, ked' vstup, ktorý by inak podnik získal z vlastných zdrojov, kúpi od iného podnikatel'ského subjektu ako službu, prípadne ako výrobok“.

Outsourcing sa vorganizáciách či už súkromného alebo verejného sektora využíva predovšetkým z dôvodu, že subjekt sa chce zamerat' na rozvíjanie svojich prioritných činností a činnosti sekundárne presúva na zabezpečenie dodávatel'ovi. S implementáciou outsourcingu sú spájané mnohé očakávané pozitívne efekty, no bohužial' realizácia outsourcingu v organizácii zároveň znamená i potenciálne riziká. Kladné efekty a riziká sú prehl'adne zobrazené v nasledujúcich tabul'kách (Jirásková, 2006). 
Tabul'ka 2 Výhody uplatňovania outsourcingu

\begin{tabular}{|c|c|}
\hline $\begin{array}{c}\text { Výhody uplatňovania } \\
\text { outsourcingu } \\
\text { v podnikatel'skej sfére }\end{array}$ & $\begin{array}{l}\text { Výhody uplatňovania outsourcingu v rezorte } \\
\text { obrany }\end{array}$ \\
\hline $\begin{array}{ll}\text { - } & \text { dlhodobé zníženie a kontrola } \\
& \text { nákladov } \\
\text { - } & \text { skvalitňovanie hlavnej činnosti } \\
\text { - } & \text { podpora kl'účových kompetencií } \\
& \text { manažérov } \\
\text { - } & \text { ekonomická výhodnost' } \\
\text { - } & \text { presun zodpovednosti } \\
& \text { (znižovanie rizika) } \\
\text { - } & \text { plánovanie finančných zdrojov }\end{array}$ & $\begin{array}{ll}\text { - } & \text { zameranie sa na dosahovanie primárneho ciel'a } \\
\text { - } & \text { efezortu } \\
\text { - } & \text { zabeztívnejšie využenivanie obrany štátu } \\
\text { - } & \text { zníženie nákladov a súčasné zvýšenie kvality } \\
& \text { zabezpečovaných služieb } \\
\text { - } & \text { presun zodpovednosti a rizík na súkromný sektor } \\
\text { - } & \text { transparentnost' }\end{array}$ \\
\hline
\end{tabular}

Zdroj: vlastné spracovanie

Tabul'ka 3 Riziká uplatňovania outsourcingu

\begin{tabular}{|c|c|}
\hline $\begin{array}{c}\text { Riziká spojené s využitím outsourcingu } \\
\text { v podnikatel'skej sfére }\end{array}$ & $\begin{array}{l}\text { Riziká spojené s využitím } \\
\text { outsourcingu v rezorte obrany }\end{array}$ \\
\hline 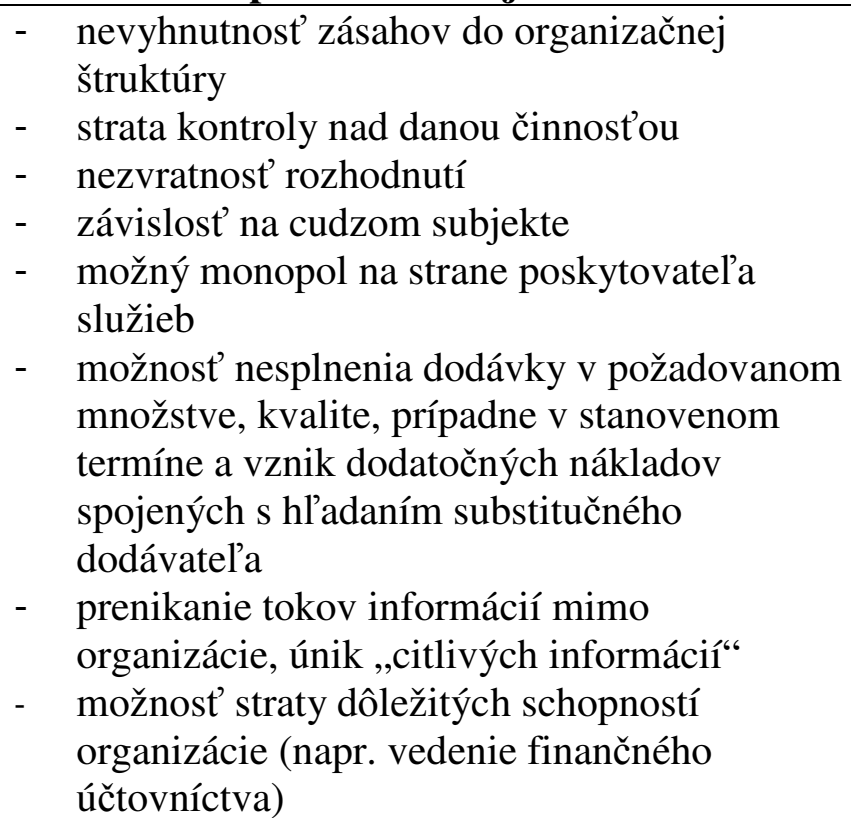 & $\begin{array}{ll}\text { - } & \text { vznik korupčného prostredia } \\
\text { - } & \text { zložité a nákladné zmluvné } \\
& \text { vzt'ahy } \\
\text { - } & \text { možné zadlženie budúcich } \\
\text { generácií } \\
\text { - } \\
\text { možné riziká pri poskytovaní } \\
\text { služieb v prípade vojenského } \\
\text { konfliktu (vystavovanie } \\
\text { súkromných firiem bojovým } \\
\text { rizikám) } \\
\text { - } \\
\text { problémy so zabezpečovaním } \\
\text { služieb v bojových operáciách } \\
\text { mimo územia štátu }\end{array}$ \\
\hline
\end{tabular}

Zdroj: vlastné spracovanie

Podstata tejto metódy bola využitá i pri transformácii ozbrojených síl mnohých štátov. Implementácia outsourcingu v rezorte obrany Slovenskej republiky logicky vyplynula z profesionalizácie ozbrojených síl. Profesionálna armáda ako subjekt verejného sektora sa zaoberá produkciou verejnej služby - národnej obrany a bezpečnosti. Transformácia výrobných zdrojov sa uskutočňuje špecifickou technológiou, vojenským výcvikom, ktorý môže mat' charakter všeobecného alebo špecifického výcviku. Tieto aktivity možno považovat' za primárnu činnost' ozbrojených síl. Kvalitné zabezpečenie obrany je však podmienené i nevyhnutným vykonávaním rozličných pomocných činností, ktoré boli vobdobí pred profesionalizáciou armády zabezpečované prevažne vojakmi povinnej 
základnej služby. Ked’že táto kategória vojakov bola v ozbrojených silách zrušená, ${ }^{1}$ bolo vo vedení ozbrojených síl rozhodnuté zaviest' v oblasti vojenskej logistiky outsourcing z dôvodu nedostatku personálnych zdrojov. Išlo o zavedenie nového spôsobu zabezpečovania služieb, s ktorým nebolo dostatok skúseností, čo so sebou prinieslo i rozličné problémy.

V snahe prispiet' k odstráneniu chýb a negatívnych javov pri riadení outsourcingových procesov bola v rokoch 2009 - 2011 na Katedre manažmentu Akadémie ozbrojených síl gen. M. R. Štefánika v Liptovskom Mikuláši riešená rezortná vedecká úloha pod názvom „Zvýšenie efektívnosti realizácie logistických služieb formou outsourcingu v logistike rezortu obrany Slovenskej republiky“. V rámci jej riešenia bol uskutočnený prieskum outsourcingu v interných organizačných jednotkách vykonávajúcich svoju činnost’ v rámci rezortu obrany.

Ciel'om prieskumu bolo zistit' ako interné organizačné jednotky pristupujú k praktickej realizácii outsourcingu, overit', do akej miery sa rešpektujú overené postupy a metódy riadenia outsourcingu $\mathrm{v}$ jednotlivých etapách životného cyklu outsourcingových projektov, akým spôsobom sú vypracované outsourcingové zmluvy a zistit', či prax korešponduje $s$ teóriou.

Zámerom riešenia vedeckej úlohy bolo zároveň spracovat' získané údaje a na ich základe formulovat' odporúčania adresované pracovníkom podiel'ajúcim sa na riadení outsourcingových vzt'ahov, ktoré by viedli k zvýšeniu účinnosti riadenia a k efektívnejšiemu využívaniu disponibilných zdrojov.

\section{Metodika prieskumu}

Predmetom skúmania bol proces outsourcingu uskutočňovaný vinterných organizačných jednotkách ozbrojených síl. $\mathrm{Z}$ techník vedeckého výskumu určených na získanie údajov, s ohl'adom na stanovený ciel', bola zvolená okrem obsahovej analýzy dokumentov aj dotazníková metóda a metóda riadeného rozhovoru.

Ciel'ovou skupinou prieskumu boli interné organizačné jednotky (vojenské útvary, úrady a zariadenia) vykonávajúce svoju činnost' v rámci rezortu obrany Slovenskej republiky. Výberový súbor prieskumu predstavoval 34 subjektov.

Dotazník obsahoval 26 systematicky usporiadaných otázok rozdelených do dvoch kategórií: identifikačná čast' ( 2 otázky), informačná čast' (24 otázok). Informačná čast' bola pomocou filtračnej otázky rozdelená do 3 celkov, a to: pre interné organizačné zložky, v ktorých je outsourcing už využívaný, v ktorých sa outsourcing plánuje využívat' a v ktorých sa outsourcing neplánuje využívat'. V dotazníku boli respondentom položené uzavreté/dichotomické otázky s pevným výberom odpovedí (áno - nie), výberové otázky, ktoré mali respondentom umožnit' volit' zo širšieho diapazónu odpovedí, poradové otázky (na zistenie poradia jednotlivých alternatív), škálované otázky (so 4 možnými odpoved’ami), polootvorené i otvorené otázky, v ktorých respondenti mohli uviest' svoj názor na skúmanú problematiku. V dotazníku bol pre respondentov tiež vymedzený priestor na vyjadrenie ich názorov a pripomienok $\mathrm{k}$ danej problematike.

\footnotetext{
${ }^{1}$ Ozbrojené sily Slovenskej republiky začali fungovat’ ako plne profesionálna armáda od 1. 1. 2006.
} 


\section{Výsledky a diskusia}

Zo získaných údajov vyplynulo, že 29 interných organizačných jednotiek outsourcing už realizuje, 3 organizačné jednotky outsourcing plánujú využívat' (vdvoch z nich sa outsourcing už realizuje a zároveň sa plánuje realizovat' aj v d'alších oblastiach) av 4 organizačných jednotkách neplánujú outsourcing využívat'.

Vzhl'adom na často proklamované negatívne názory na zmenu spôsobu zabezpečovania pomocných činností v Ozbrojených silách Slovenskej republiky a tvrdenia, že outsourcing oproti internému spôsobu zabezpečovania služieb nie je výhodný, znamená podstatné zvýšenie nákladov, organizačné problémy a výrazný pokles kvality zabezpečovaných služieb, sme predpokladali, že v jednotlivých organizačných jednotkách sa v plnej miere neuplatňujú odporúčané postupy pri výbere dodávatel’ov služby, outsourcingové zmluvy nie sú vypracované dostatočne kvalitne a riadenie outsourcingových vzt'ahov v nedostatočnej miere rešpektuje odporúčané postupy a metódy, tzv. vzorové praktiky riadenia (best practices), čoho následkom je vznik negatívnych efektov v praxi.

Na základe odpovedí respondentov sme dospeli k zisteniam, ktoré sú prehl'adne uvedené v Tabul'ke 4 a Tabul'ke 5.

Tabul'ka 4 Súlad postupu interných organizačných jednotiek s odporúčaniami v prípade aktivít zadávatel'a

\begin{tabular}{|l|c|}
\hline Aktivity zadávatel'a & $\begin{array}{c}\text { Súlad } \\
\text { s odporúčaniami v \% }\end{array}$ \\
\hline Doba prípravy na outsourcing & 86,20 \\
\hline Využívanie konzultačných služieb & 93,10 \\
\hline Metóda výberu dodávatel'a & 87,87 \\
\hline Posudzovanie viacerých kritérií pri výbere dodávatel'a & 96,56 \\
\hline Vykonaná analýza nákladov & 72,41 \\
\hline Oboznámenie pracovníkov so zmenami & 72,41 \\
\hline Odborné vyškolenie pracovníkov & 62,06 \\
\hline Uplatnené projektové riadenie & 31,03 \\
\hline Členmi projektového tímu boli aj pracovníci dodávatel'skej firmy & 6,89 \\
\hline Doba na ktorú sú uzatvorené outsourcingové zmluvy & 41,38 \\
\hline Kvalita služby je pravidelne kontrolovaná a posudzovaná & 96,55 \\
\hline Vypracovaný systém hodnotiacich metrík & 17,24 \\
\hline Monitorovanie a riadenie rizík & 48,27 \\
\hline Vyhodnocovanie pozitívnych a negatívnych efektov outsourcingu & 48,27 \\
\hline Prehodnocovanie rozhodnutia outsourcovat' službu & 41,37 \\
\hline Postup v prípade konkurzu dodávatel'a & 13,79 \\
\hline
\end{tabular}

Zdroj: vlastný prieskum 
Tabul'ka 5 Súlad postupu interných organizačných jednotiek s odporúčaniami v prípade údajov uvádzaných v outsourcingovej zmluve

\begin{tabular}{|l|c|}
\hline Údaje uvádzané v outsourcingovej zmluve & $\begin{array}{c}\text { Súlad } \\
\text { s odporúčaniami v \% }\end{array}$ \\
\hline Kvalitatívne parametre & 89,65 \\
\hline Kvantitatívne parametre & 68,96 \\
\hline Pokyny akým spôsobom sa majú aktivity vykonávat' & 72,41 \\
\hline $\begin{array}{l}\text { Zodpovednost', sankcie a nároky vyplývajúce z porušenia } \\
\text { zmluvných povinností }\end{array}$ & 93,10 \\
\hline Možnost' cenových úprav za poskytované služby & 44,82 \\
\hline Podmienky a možnost' výpovede zmluvy & 100,00 \\
\hline Možnost' predíženia zmluvy na d'alšie obdobie & 48,27 \\
\hline Súhlas poskytovatel'a s monitorovaním a kontrolou výkonu služieb & 65,51 \\
\hline
\end{tabular}

Zdroj: vlastný prieskum

Ako možno vidiet' z uvedených údajov, interné organizačné jednotky vo viacerých parametroch nerešpektovali odporúčania, ktoré ponúka teória manažmentu outsourcingu.

Priemerná doba outsourcingových zmlúv bola 2,18 roka, pričom prevažovali zmluvy uzatvárané na 1 rok (približne 60\% zmlúv). Tento stav je odlišný v porovnaní s vyspelými štátmi, kde sa za optimálnu dobu trvania outsourcingového vzt’ahu považuje obdobie 5 až 10 rokov (minimálne 2-3 roky), pričom jedným z hlavných kritérií určujúcich dížku kontraktu je typ outsourcingu. Stanovenie optimálnej doby trvania zmluvy závisí od ciel'a, ktorý sa má outsourcingom dosiahnut' a od charakteru poskytovanej služby. Aby sa dosiahli pozitívne efekty s dôrazom na uplatňovanie win-win stratégie, malo by íst' o vzt'ah dlhší. Striedanie outsourcingových partnerov zo strategického hl'adiska je možné považovat' za nevhodné, a to z dôvodu, že ak má outsourcing priniest' pozitívne efekty, subjekt by mal spolupracovat' s takým partnerom, ktorý vie profesionálne mysliet' a ktorý je dlhodobo oboznámený s činnost'ou organizácie. Zároveň by mal svoju činnost' vykonávat' tak, aby podporoval naplnenie hlavných ciel'ov zadávatel'a. Každoročným opakovaním výberových konaní sa zároveň zvyšujú transakčné náklady súvisiace s nájdením vhodného partnera. Z týchto dôvodov je vhodné v prípade bezproblémových vzt’ahov a pozitívnych skúseností zo spolupráce s konkrétnym dodávatel'om služby uzatvárat' zmluvy na dlhšie obdobie (3 - 5 rokov). Outsourcingové zmluvy sa môžu podpisovat' na kratšiu dobu s možnost'ou ich opätovného uzatvorenia, prípadne predíženia. Zároveň by organizácia mala mat' jasne stanovený postup, akým spôsobom sa môže outsourcingový vzt'ah predížit', či ukončit' a ako prejde k inému dodávatel'ovi. Uplatňovaním takéhoto postupu sa organizácii zvyšuje manévrovacia schopnost' pri opätovnom prehodnocovaní rozhodnutia v prospech alebo neprospech outsourcingu, prípadne pri výbere konkrétneho dodávatel'a. Tento prístup sa uplatňuje aj v ozbrojených silách, ked’ zmluvy sú uzatvárané na kratšiu dobu, no v 48,27\% zmlúv je uvedená možnost' ich predíženia.

Za značný nedostatok je možné považovat', že pri zavádzaní outsourcingu sa v plnej miere neuplatnilo projektové riadenie, pričom členmi projektových tímov neboli i pracovníci dodávatel'ských firiem. Subjektom zavádzajúcim outsourcing je možné odporučit', aby zainteresovali do prípravy a riadenia outsourcingového vzt'ahu aj pracovníkov dodávatel'a služieb. Najčastejšou chybou pri implementácii outsourcingu je jeho ponímanie ako jednorazového aktu a nie ako procesu vyžadujúceho projektové riadenie v celom životnom cykle. Už v procese výberu dodávatel'a by zadávatel' mal od záujemcov vyžadovat' ich návrhy na invenčné a efektívne riešenie poskytovania služby. Aj počas trvania outsourcingového 
vzt'ahu je výhodné motivovat' a zainteresovat' dodávatel'a na hl'adaní skrytých rezerv pri zabezpečovaní služby.

Prehodnocovanie rozhodnutia outsourcovat' službu sa uskutočňuje v 41,37\% subjektov. Ked'že proces outsourcovania služby podlieha zmenám včase (mení sa externé okolie i vnútorné prostredie organizácie), je ho nevyhnutné permanentne analyzovat' a následne robit' patričné riadiace opatrenia. V prípade nutnosti je vhodné projekt modifikovat', aby sa $\mathrm{v}$ dostatočnej miere reagovalo na prebiehajúce zmeny.

V prieskume bolo zistené, že 20,69\% interných organizačných jednotiek malo v prípravnej fáze problém s identifikáciou rizík, ktoré by mohli negatívnym spôsobom ovplyvnit' úspešný priebeh outsourcingu. Možno povedat', že oblasti rizík spojených s implementáciou outsourcingu v interných organizačných jednotkách je celkovo venovaná malá pozornost'. Iba $48,27 \%$ interných organizačných jednotiek sa venuje monitorovaniu a riadeniu rizík. Tento stav je možné hodnotit' ako nedostatočný. Situácia zrejme vyplýva zo skutočnosti, že problematika riadenia rizík súvisiacich s outsourcingom je $\mathrm{v}$ súčasnosti $\mathrm{v}$ informačných zdrojoch rozpracovaná len vo všeobecnej rovine, a to prevažne pre subjekty súkromného sektora. Podrobnejšia metodika pre identifikáciu, monitorovanie a riadenie rizík súvisiacich s outsourcingom uplatňovanom $v$ špecifickom vojenskom prostredí však absentuje. Prieskumom bol identifikovaný vel'mi závažný problém, a to, že v ozbrojených silách v súčasnosti nie je inštitucionálne riešené riziko súvisiace s dodávaním služieb v prípade vyhlásenia mobilizácie a vojnového stavu.

Čo sa týka posúdenia náležitostí, ktoré by mala obsahovat' outsourcingová zmluva, možno zhodnotit', že ani v tomto prípade interné organizačné jednotky nepostupujú v plnej miere s odporúčaniami. Spokojnost' možno vyjadrit' iba v prípade uvádzaných podmienok pre vypovedanie zmluvy, ktoré sú uvedené v každej uzatvorenej zmluve. V 89,65\% zmlúv sú špecifikované kvalitatívne parametre a v 68,96\% kvantitatívne parametre poskytovaných služieb. Kvalitatívne parametre sú napr. pri službe stravovania: počet st’ažností uvedený v knihe prianí a st’ažností, dohodnuté energetické a nutričné hodnoty zložiek stravy uvedené v zmluve. Kvantitatívne parametre: gramáž porcií, počet objednaných a vydaných jedál, presne stanovená doba výdaja jedál.

Pokyny akým spôsobom sa majú aktivity vykonávat' chýbajú v 27,59\% zmlúv. Zároveň v niektorých prípadoch $(6,90 \%)$ nie je v zmluve uvedená zodpovednost', sankcie a nároky vyplývajúce z porušenia zmluvných povinností. Negatívne možno hodnotit' i skutočnost', že v 34,49\% zmlúv chýba súhlas poskytovatel'a služby s monitorovaním a kontrolou výkonu služieb.

Prieskum preukázal, že vyhodnocovanie pozitívnych a negatívnych efektov outsourcingu sa uskutočňuje v 48,27\% subjektov. Ak proces outsourcingu nie je podrobovaný pravidelnému vyhodnocovaniu, nemožno predpokladat', že budú riadiacimi zásahmi odstraňované príčiny negatívnych efektov a ani sa nemôžu formulovat' návrhy na zlepšenia.

Jednou z možností ako predchádzat' opakovaniu starých chýb je využitie metódy Lessons Learned. Pracovníci zodpovední za riadenie outsourcingových vzt'ahov by mohli do databázy vkladat' poznatky, na základe svojich skúseností. Ako mimoriadne vhodné pre zaradenie do databázy sa javia pokyny ako správne postupovat' pri riadení outsourcingu, vyplývajúce zo záverov riešenia vedeckej úlohy. Databáza procesu Lessons Learned by mala byt jedným z najdôležitejších nástrojov na podporu vojenských velitel'ov pri vydávaní potrebných 
rozhodnutí na odstránenie nedostatkov a na zaznamenávanie, zlepšovanie a zverejňovanie najlepších postupov. Zároveň je potrebné, aby v každom jednotlivcovi v súvislosti s učením sa a využívaním skúseností iných prebehol nasledovný proces (Burger, 2010):

1. Spoznat' novú praktiku (preštudovat' podklady).

2. Porozumiet' jej podstate a hodnote (v diskusii).

3. Akceptovat' zmenu, t. j. mentálne prijat' myšlienku, že nová praktika je užitočná a odhodlat' sa ju zvládnut' a používat'.

4. Vyskúšat' si praktiku, zistit' akú má hodnotu.

5. Adaptovat' ju do svojich podmienok.

6. Fixovat' jej používanie.

7. Používat' novú praktiku rutinne a zavŕšit' tak proces jej rozšírenia.

Z prieskumu vyplynulo, že profesionálni vojaci majú výrazný záujem zdiel'at' a využívat' získané skúsenosti/poznatky. Až $90 \%$ respondentov pokladá za dôležité budovat' v rámci ozbrojených síl kultúru zameranú na zdiel'anie získaných skúseností. Súčasnú úroveň zdiel'ania poznatkov označili respondenti za priemernú (Haviar, 2012). Je treba si uvedomit', že pracovník ako individuálna osobnost' poskytne svoje skúsenosti a poznatky do systému len vtedy, ak v tom uvidí prínos. Z tohto dôvodu je potrebné, aby velitelia vhodným spôsobom motivovali svojich podriadených kaktívnemu využívaniu databázy systému Lessons Learned. Zo strany nadriadených je zodpovedné identifikované nedostatky odstraňovat', a nie svojich podriadených za nedostatky postihovat'.

Medzi profesionálnymi vojakmi je potrebné zvýšit' ich informovanost' o procese Lessons Learned. Profesionálnym vojakom, ktorí sa na jednotlivých stupňoch velenia a riadenia venujú tejto metóde je možné túto činnost' zahrnút' do ich opisu funkčnej náplne. Tento krok by viedol $\mathrm{k}$ väššej angažovanosti zodpovedných pracovníkov. Z uvedeného vyplýva, že existuje reálny predpoklad, aby systém Lessons Learned prispel k rozvoju a zlepšeniu práce i v oblasti manažmentu outsourcingu.

\section{Záver}

Úlohou znalostného manažmentu pri budovaní znalostnej organizácie je vytvárat' podnikovú kultúru vedúcu zamestnancov k učeniu sa a k zdiel'aniu informácií, znalostí a svojich skúseností. Zavádzanie znalostného manažmentu predstavuje pre manažérov mnohokrát vel'kú výzvu a nie vždy sa dosiahnu pozitívne výsledky. Manažéri si musia uvedomit', že úspech vybudovania organizácie využívajúcej znalosti spočíva nielen vo vybudovaní kvalitného informačného systému, ale aj od faktu, že znalosti nemôžu byt' odtrhnuté od l'udí, pretože sa jedná o nehmotný duševný majetok, ktorý je treba riadit'.

Aby boli dosiahnuté predpokladané kladné efekty spájané so zavedením systému Lessons Learned, musia byt' splnené nasledovné predpoklady (Zůna, 2008):

1. Každý pracovník musí mat’ čas vyhl'adat' si v databáze príslušnú informáciu.

2. Pracovník musí vediet', kde môže informáciu nájst'.

3. Pracovník musí vediet' používat' software spravujúci informácie.

4. Pracovník musí dokázat’ správne interpretovat’ a využit’ nájdenú informáciu.

Tento príspevok bol spracovaný ako súčast’ riešenia Projektu vedy a výskumu č. VV5 - 2012 „Rozvoj l'udských a materiálových zdrojov v rezorte obrany SR“. 


\section{Literatúra:}

[1] BURGER, I. Podnikový knowledge Management - konkurenčná výhoda. In Manažér, roč. 15, 2010, č. 2. ISSN 13-35-1729

[2] HAVIAR, P. Možnosti využitia metódy Lessons Learned v budovaní znalostnej organizácie. Diplomová práca. Liptovský Mikuláš: Akadémia ozbrojených síl gen. M. R. Štefánika, 2011.63 s.

[3] JIRÁSKOVÁ, S. Proces scivilňovania služieb - zavádzanie outsourcingu v rezorte Ministerstva obrany SR [online]. In Manažment v teórii a praxi [elektronický zdroj] : on-line odborný časopis o nových trendoch v manažmente. ISSN 1336-7137. Roč. 2, č. 3-4 (2006) [cit. 2012.08.28.]. Dostupné na internete: http://casopisy.euke.sk/mtp

[4] JIRÁSKOVÁ, S. Možnosti využitia systému Lessons Learned pri budovaní znalostnej organizácie. In Economics and management Ekonomika a management, roč.5, 2011, č.3. ISSN 1802-3975

[5] KUDLIČKA, K. Získavání a vyhodnocení poznatků a zkušeností v praxi [online]. In Doktríny. ISSN 1803-036X, 2010, roč.3, č.1. [cit. 2012.08.28.] Dostupné na internete: http://doctrine.vavyskov.cz/_casopis/2010_2/2010_2_3d.pdf

[6] LEDNICKÝ, V. Outsourcing a jeho aktuální podoby používané v současné době. In Sborník výzkumných prací Ústavu malého a středního podnikání Díl 9. Karviná: Slezská univerzita v Opavě, 2004. ISBN 80-7248-274-2.

[7] MAJCHÚT, I. Nerobme rovnaké staré chyby. In Zborník príspevkov z medzinárodnej vedeckoodbornej konferencie „Manažment - Teória, výučba a prax 2010. Liptovský Mikuláš: Akadémia ozbrojených síl gen. M. R. Štefánika, 2010. ISBN 978-80-8040-404-8

[8] ZŮNA, P. Místo a poslání Lessons Learned v procesech velení a řízení z pohledu moderní teorie managementu. In Zborník z vedecko-odbornej konferencie „Management teorie a praxe ve vojenském prostředi““. Brno: Univerzita obrany, 2008. ISBN 978-80-7231-562-8

\section{JEL H41, H44}

\section{Ing. Soňa Jirásková, PhD.}

Odborný asistent Katedra manažmentu

Akadémia ozbrojených síl gen. M. R. Štefánika

Demänová 393

03101 Liptovský Mikuláš, SR

sona.jiraskova@aos.sk 